\title{
PERAN CAHAYA DARI JENDELA PADA FOTO ALAM BENDA (Konfigurasi Objek, Cahaya dan Komposisi)
}

\author{
Nofria Doni Fitri \\ Sekolah Tinggi Senirupa dan Desain Visi \\ donifitri13@gmail.com
}

\begin{tabular}{|c|c|}
\hline ARTICLE INFO & ABSTRACT \\
\hline $\begin{array}{l}\text { Article history: } \\
\text { Received: } 20 \text { Oktober } 2017 \\
\text { Revised: } 01 \text { November } 2017 \\
\text { Accepted: } 20 \text { November } 2017\end{array}$ & $\begin{array}{l}\text { Enchantment of still life Photography is often seen from the unique } \\
\text { side of the real object. Obsolete objects age consumed by the } \\
\text { photographer is commonly chosen as a photo object. In addition to } \\
\text { reviving memories of these objects, old artifacts are alwavs }\end{array}$ \\
\hline $\begin{array}{l}\text { Keywords: } \\
\text { Lighting } \\
\text { Object } \\
\text { Composition }\end{array}$ & $\begin{array}{l}\text { interesting to see because they are rarely found today. Photographs } \\
\text { of identical objects with art photographs are created to meet the } \\
\text { aesthetic satisfaction of the photographer and are free from } \\
\text { commercial purposes. Objects with the uniqueness of the form have a } \\
\text { specific meaning for the photographer, life experiences that intersect } \\
\text { with the object it becomes the reason to choose it as an object. In } \\
\text { addition to the physical quality of the object, there is another factor } \\
\text { that is not less for an object as an object, namely light, and } \\
\text { composition. How the process of making a still life object by the } \\
\text { window lighting of the work of Bertina De Moiij so it has a good } \\
\text { dimension. In this discussion will be disclosed. }\end{array}$ \\
\hline
\end{tabular}

\section{PENDAHULUAN}

Peristiwa fotografi berawal dari seberkas sinar yang memproyeksikan objek masuk melalui lubang kecil ke dalam kotak kedap cahaya. Kotak kecil tersebut disebut ruang yang digelapkan dan kini dikenal dengan istilah kamera. Cara kerja kamera dilakukan dengan menggunakan selembar kertas foto peka cahaya diletakkan di dalam kamera. Kertas foto peka cahaya ini mampu menyimpan bayangan objek. Kemudian dengan menggunakan larutan kimia, image yang tersimpan tadi dikembangkan, ditetapkan atau dikuatkan dan terciptalah sebuah gambar (foto) di atas selembar kertas yang disebut fotografi.

Sejarah panjang fotografi tidak dapat dipisahkan dari foto alam benda. Foto pertama yang berjudul "View from the Window at Les Gras" dengan objek susunan rumah-rumah di Paris karya Joseph Nicephore Niepce (1826) yang dipotret dari ruang kerja di lantai atas rumahnya merupakan foto alam benda dalam skala besar. Foto itu memperlihatkan rumah yang diterangi oleh sinar matahari sebagai sumber cahaya utama. Pada prinsipnya objek pada foto tersebut sama seperti foto benda mati di sudut meja, dipotret dari jarak dekat yang terkena sinar matahari dari luar dalam arti skala kecil. 


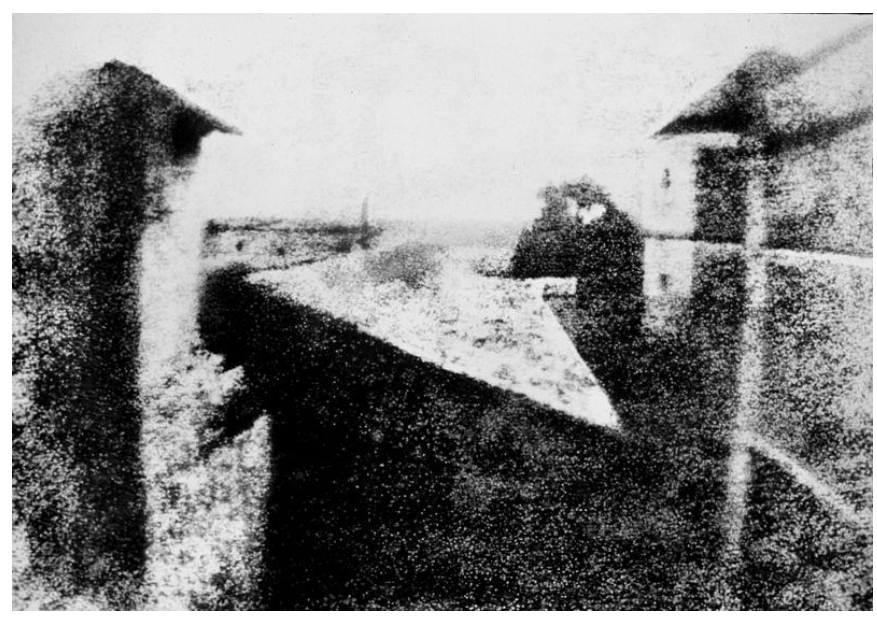

Gambar 1. Foto karya Joseph Nicephore Niepce. (Sumber: Rosenblum, 1984:19)

Aspek utama pada fotografi adalah cahaya. Cahaya membantu kita melihat keindahan alam, begitu juga benda. Cahaya matahari dengan sinar putih (netral) masuk melalui jendela cahaya ini akan menentukan dimensi (gelap-terang) pada objek. Cahaya yang masuk melalui jendela terpancar lurus langsung mengenai objek atau cahaya tersebut terbiaskan (cahaya tak langsung) keduanya dapat digunakan untuk memotret alam benda dengan baik.

Teknik window lighting pada fotografi diadopsi dari seni lukis. Pada awalnya teknik ini digunakan Rembrant Van Rinj (pelukis Belanda) yang melukis modelnya di dekat jendela. Rembrant memanfaatkan cahaya dari jendela yang mengenai wajah model lukisannya. Wajah yang digambarnya telihat jelas dan di bagian pinggir (outline) model dikaburkan dengan sapuan kuas. Ahkirnya wajah model tadi seperti muncul dari kegelapan karena ruang studio lukisnya hanya diterangi oleh cahaya dari jendela.

Pada perkembangannya foto alam benda sering dijadikan media untuk penyampaian pesan secara simbolis dalam mengekspresikan seni bagi fotografer (seniman). Selain media ekspresi, melalui foto alam benda pula identitas suatu daerah dapat disampaikan. Foto alam benda mampu menggerakkan perasaan dan alam bawah sadar audiens pada pengalamanpengalaman masa lalu mereka yang bersinggungan dengan benda-benda tertentu.

Foto alam benda (still life) pada umumnya dibuat di dalam studio dengan pencahayan yang sudah mapan. Apakah cahaya menjadi aspek utama pada foto alam benda yang menjadi kekuatan fotografi untuk menggerakkan perasaan audien atau membuat benda mati terkesan hidup? Apakah cahaya dari jendela dapat optimal digunakan bergitu saja atau perlu direkayasa? Sehingga cahaya sudah lebih baik dalam melukis alam benda, dilihat pada foto "Kenangan Lama" karya Bertina. 
Foto alam benda sering ditemukan pada kartu ucapan selamat Idul Fitri, tahun baru dan ulang tahun. Walaupun dalam perkembangannya kartu ucapan ini dikirimkan melalui surat elektronik dan media sosial namun fungsinya tetap sama. Objek yang dipilih adalah benda-benda yang disukai pemotret dan media penyampaian pesan khusus, menampung ekspresi fotografer. Dengan menguasai teknik window lighting, penggemar fotografi dapat bereksperimen sendiri dan lebih mendekatkan rasa mereka pada objek yang disukainya.

Foto still life, adalah menciptakan sebuah gambar dari benda mati agar tampak jauh lebih hidup dan berbicara, bila objeknya makanan akan tampak lebih hangat, dingin, atau lembut. Kata "still" berarti diam atau benda yang mati, sedangkan "life" berarti hidup dan memberikan konteks "tampak hidup" pada benda tersebut. Alam benda (still life) adalah objek foto yang dapat diatur sedemikian rupa oleh pemotret demi memenuhi hasrat kepuasan seni dan bebas dari tujuan komersial. Sebuah benda dipilih sebagai objek foto didasari kesenangan dan kedekatan fotografer pada objek tersebut. Benda sebagai objek foto memiliki arti yang spesifik bagi fotografer. Beragam pengalaman yang beririsan dengan benda tersebut dapat disalurkan melalui foto alam benda. Foto alam benda mampu menggerakkan perasaan serta alam bawah sadar manusia atas pengalaman masa lalu mereka yang bersinggungan dengan benda-benda tertentu. Melalui foto alam benda identitas suatu daerah pun dapat disampaikan. Dalam pembahasan ini akan diungkap bagaimana menciptakan foto alam benda yang baik dengan cara praktis. Pemanfaatan cahaya dari jendela dapat dijadikan acuan untuk menciptakan foto alam benda yang baik. Bagaimana dimensi pada foto alam benda dapat dipengaruhi oleh kualitas cahaya dan bagaimana mengendalikan cahaya yang datang dari jendela dengan optimal menjadi konsentrasi utama pada bahasan foto "Kenangan Lama” karya Bertina De Moij.

Still life Photographer adalah pemotret yang bekerja mulai dari menentukan objek foto, sesuatu yang belum ada menjadi ada. Fotografer menyediakan objek, dan property foto sendiri, kemudian menyususun objek-objek dalam sebuah komposisi serta menentukan pencahayaan untuk fotonya. Dalam mengatur komposisi fotografer harus punya konsep dan teknik penataan yang matang. Pemilihan objek selain disukai oleh pemotretnya (subjektif), juga memenuhi kualitas kebentukan yang baik. Secara visual pemilihan mempertimbangkan bentuk yang unik dan menarik, nilai raba (tektur) karena objek bertekstur paling tepat untuk cahaya dari jendela. Fotografer harus menguasai semua objek dan bidang yang terlihat pada fotonya. Ia mengkonfigurasikan aspek tersebut untuk menciptakan pesan melalui fotonya.

Pada foto alam benda karya Bertina De Moij (mahasiswa asal Perancis yang menempuh pendidikan di STSRD VISI) yang berjudul "Kenangan Lama" sepintas terlihat indah dan 
menarik perhatian. Tinjauan akan dilakukan pada aspek cahaya dan komposisinya yang menjadikan karya tersebut terlihat artistik. Karya ini dijadikan ilustrasi pada poster pameran tahun 2010. Tinjauan akan dilihat dari sudut: (1) Apakah foto "Kenangan Lama" memperhatikan cahaya dan pengaturan komposisinya dengan baik?; (2) Apakah foto "Kenangan Lama" memperhatikan prinsip-prinsip keseimbangan (balance), kesatuan (unity), irama (rhythm) dan kesatuan (unity) kesatuan antar unsur-unsur rupa?

Cahaya ditinjau dari arah datang sinarnya dapat dibedakan menjadi empat macam. Pertama, cahaya depan (front lighting) yaitu cahaya datang dari belakang fotografer dan memnyinari suluruh objek dari depan, objek akan terlihat jelas dan warna objek tampil dengan sempurna, cahaya dari depan menciptakan efek datar (flat) sehingga suasana ( $m o o d$ ) kurang terbangun. Kedua, cahaya belakang (backlighting), cahaya datang dari belakang objek dan menghadap ke pemotret. Cahaya belakang menimbulkan garis cahaya di pinggir objek (rim lighting) jika latar belakang gelap dan baik untuk gesture atau shape (siluet). Ketiga, cahaya atas atau bawah objek, arah cahaya seperti ini menjadikan objek tampil kurang informatif dan mengaburkan informasi objek. Keempat, cahaya dari samping objek termasuk (window lighting) terbukti cukup efektif memunculkan tekstur pada benda sekaligzus menciptakan efek tiga dimensi (kedalaman) dari objeknya.

Definisi window lighting adalah cahaya yang masuk melalui jendela baik langsung atau cahaya yang terbiaskan hingga mengenai subjek foto dari samping di dalam ruangan. Pencahayaan samping (side light) terbukti merupakan ekposur yang penuh tantangan bagi banyak fotografer karena kombinasi highlight dan shadow-nya. Tetapi itu juga memberikan banyak kesempatan pengambilan-gambar yang paling mengagumkan. Seperti yang pasti disepakati banyak fotografer profesional, subjek yang tercahayai dari samping-melebihi yang tercahayai dari depan atau dari belakang - memperoleh respon yang jauh lebih kuat dari para penikmat foto, karena foto itu menstimulasi dengan lebih baik dunia tiga dimensi yang mereka lihat. Indirect window light menciptakan soft shadows sehingga bagian area gelap masih dapat dilihat detailnya, sedangkan highlight menjadi berkurang intensitasnya kerena akibat terhalang kaca atau tirai jendela (Peterson, 2010).

Pada umumnya benda sebagai objek foto dipotret begitu saja seperti apa adanya ia ditemukan. Fotografer tanpa memperhitungkan arah dan kekuatan cahaya yang baik untuk objek sehingga emosi dan suasana pada foto alam benda tidak terbangun. Dalam fotografi alam benda penting untuk memperlihatkan karakter permukaan benda misalnya benda yang keras bertekstur 
kasar harus terlihat seperti aslinya. Benda dari kayu memperlihatkan serat kayunya. Logam yang berhiaskan ornamen dengan teksturnya yang menarik.

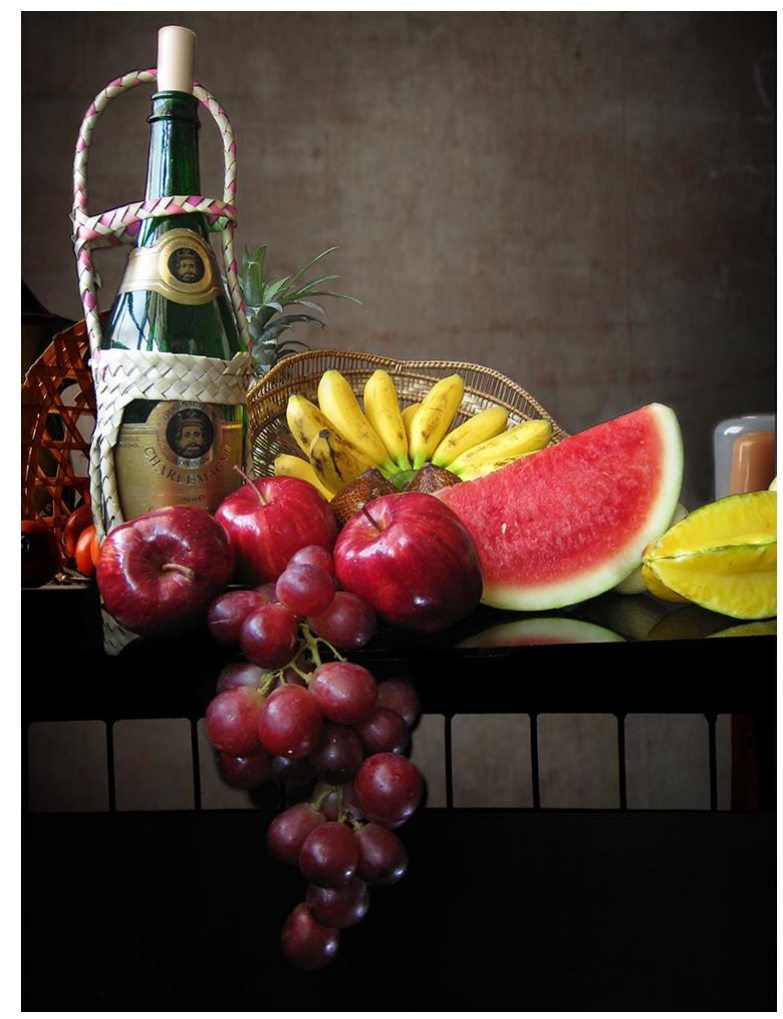

Gambar 2. Foto buah-buahan yang dipotret dengan prinsip pencahayaan dari jendela. (Sumber: Dokumentasi Penulis)

\section{METODE PENELITIAN}

Mengaplikasikan teori pencahayaan (Rembrand Lighting) dengan studi kasus foto karya Bertina De Moiij.

\section{PEMBAHASAN}

Foto alam benda adalah objek benda mati yang ditata dengan mengikuti prinsip penataan dalam desain dengan konsiderasi unsur keseimbangan (balance), irama (ryhtm), dan kesatuan (unity). Dalam konstelasi fotografi objek alam benda memperlihatkan komposisi objek dan unsur cahaya sehingga suasana ( $m o o d$ ) dapat dirasakan. Foto alam benda memperlihatkan objek benda yang memiliki kesamaan derajat dan berada dalam satu keluarga benda yang tara. Contohnya: piring, keranjang, pisau dapur, talenan, sayuran, bumbu dapur, batu gilingan cabe adalah bendabenda yang terdapat di meja dapur karena jika dihubungan objek satu dan lainnya dapat ditemukan di dapur. 
Cahaya pada fotografi alam benda difungsikan untuk dapat memunculkan suasana. Kesan kehangatan dan kesejukan dapat disampaikan melalui pencahayaan yang diberikan pada benda tersebut. Cahaya dapat membedakan objek satu dan objek lainnya. Sudut pancar cahaya mampu memisahkan satu objek dengan objek lain disebelahnya. Cahaya membantu kita untuk dapat merasakan karakter yang dimiliki oleh objek-objek foto alam benda. Singkat kata, cahaya merupakan sumber nyawa sebuah foto alam benda, tanpa cahaya tidak ada artinya susunan objek yang telah ditata dengan baik.

\subsection{Metode Pemotretan}

Fotografer alam benda harus mengetahui apa yang akan dipotret dan properti pendukungnya. Pada foto "Kenangan Lama" dipilih objek-objek tempat air dari tembaga yang tercetak tekstur ukiran dan bentuknya yang klasik. Benda-benda seperti ini sering ditempatkan dalam lemari hiasan untuk pelengkap suasana interior. Pada foto "Kenangan Lama" terlihat kemahiran pemotret dalam memahami apa yang ingin ditonjolkan pada fotonya. Buah labu yang biasa dijadikan kolak untuk berbuka di bulan puasa menjadi point of interest (POI) pada foto tersebut. Selain warnanya menonjol penampilan buah ini dalam keadaan terbelah merupakan salah satu cara untuk menciptakan kesan hidup (life). Pemilihan sudut pemotretan $20^{\circ}$ dari depan dengan lensa $85 \mathrm{~mm}$ membuat objek ini tampil wajar dan jelas. Bertina mengetahui teknik yang digunakannya dengan memasang kamera di tripod agar pengaturan cahaya lebih leluasa dilakukan. Sebelum pemotretan ia merancang layout pemotretan dan mempersiapkan bendabenda yang difungsikan sebagai pemantul cahaya (reflector). Cermin dijadikan sebagai reflector karena sifatnya yang mampu memantulkan sinar dengan optimal.

Focusing system, yang dimiliki oleh kamera DSLR ada tiga macam. Pertama, evaluative atau metrix metering. Sistem fokusing ini mengukur pencahayan seluruh bidang foto ke dalam beberapa area, kemudian mengukur seluruh bagian tersebut kemudian diambil nilai rata-rata dari penghitungan tersebut untuk mendapatkan nilai exposure yang tepat. Kedua, spot metering system, sistem ini digunakan untuk mengukur pencahayan yang memusat atau cahaya yang terkonsentrasi. Pengukuran dilakukan pada 1-5\% dari area foto atau sebagian kecil saja dari bidang. Spot metering digunakan saat subjek utama dan lingkungan sangat berbeda atau kontras tinggi. Ketiga, center weighted average, sistem ini mengukur pencahayaan pada area tengah dengan sedikit toleransi di kanan kirinya. Pengukuran ini efektif digunakan untuk mengukur pencahayaan objek yang berada di tengah dan untuk pemotretan objek/model tunggal dengan pengambilan gambar close-up. Dari ketiga jenis focusing system ini center weighted dan spot 
metering daspat digunakan untuk pemotretan objek dengan cahaya dari jendela karena sesuai dengan kondisi pencahayaan (Tjin \& Mulyadi, 2014).

Faktor kesulitan untuk foto alam benda "Kenangan Lama" adalah menentukan nilai pencahayaan (exposure value). Ada beberapa patokan yang dapat dijadikan acuan dalam penentuan nilai diafragma yaitu key light (mine light) dijatuhkan pada cahaya yang terjadi karena pantulan cermin ke objek foto atau langsung ke cahaya dari jendela. Ketetapan posisi cermin sebagai reflektor sangat diperhatikan. Setelan pada mode spot metering untuk cahaya sempit atau cahaya yang memusat memudahkan untuk diarahkan pada bagian yang diterangi oleh pantulan cahaya dari cermin.

Cermin berfungsi mengisi cahaya dari samping sekaligus berfungsi memisahkan objek satu dan lainnya. Cermin diletakkan pada penyanggah cermin untuk dudukan yang stabil sehingga posisi pemantul cahaya ini tidak berubah posisi. Tempat dudukan cermin dibuat dengan karton tebal, mirip tempat dudukan foto dilemari pajangan. Pemotretan ini mengadopsi prinsip cermin datar yaitu sudut datang sama dengan sudut pantul dan cermin adalah benda yang memantulkan cahaya hampir sama kuat dengan cahaya yang datang ke permukaannya. Efek pemantulan cahaya dengan cermin ini dapat dilihat pada karya "kenangan lama" atau karyakarya Bertina yang lain

\subsection{Skema Pemotretan}

Skema pemotretan foto "Kenangan Lama" digunakan sebagai pedoman untuk tata letak objek-objek foto dan perangkat pemotretan yang digunakan, Menggeser posisi meja tempat kedudukan objek untuk menentukan posisi arah cahaya secara dominan terhadap objek. Jika objek dipotret pada kondisi ini akan terlihat bagian gelap di sebelah kanan objek yang tidak terkena cahaya. Untuk menambah terang bagian ini digunakan pemantul cahaya (reflector) dari cermin yang berukuran $20 \times 20 \mathrm{~cm}$ sebanyak 3 buah. Asesoris pereka cahaya, seperti penghalang (gobo) diletakkan di dekat jendela dan desamping objek agak kebelakang. Gobo berupa potongan tripleks yang digunakan untuk menciptakan kesan gelap di sebelah kiri foto dan di belakang objek. Pengukuran cahaya dan penentuan key light diarahkan pada cahaya dari jendela yang jantuh ke objek terdekat dengan jendela. Karena pada bagian ini objek harus tampak normal dan objek lain dikendalikan terangnya oleh pereka cahaya tadi.

Rasio perbandingan cahaya utama dengan latar belakang yang terang tidak terlalu tinggi. Cahaya utama (mine light) lebih kuat 1 ( $f$ stop) dari cahaya latar belakang. Sedangkan cahaya pengisi yang menerangi objek dari sebelah kanan, sama dengan cahaya latar belakang. Posisi kamera dan lensa yang sudah ditetapkan memudahkan fotografer untuk mengatur tata letak 
(komposisi) objek-objek fotonya. Dalam penentuan nilai pencahayaan (exposure) dengan menggunakan mode pengukuran cahaya memusat (spot metering mode). Metering system mengukur cahaya paling terang pada objek di area fokus di dalam jendela bidik. Setelah melakukan focusing bagian-bagian yang dianggap masih kurang terang diterangi oleh reflector dengan menggesernya untuk hasil yang lebih akurat. Kedudukan cermin (reflector) sebaiknya ditetapkan supaya tidak berubah posisi selama pemotretan. Cermin dapat ditempatkan pada jepitan dengan tangkai dari alumunium yang berbentuk belalai spiral sehingga mudah diubah sudutnya sesuai keinginan. Untuk memberikan keterangan lebih jelas perhatikan gambar denah dan sketsa komposisi objek foto.

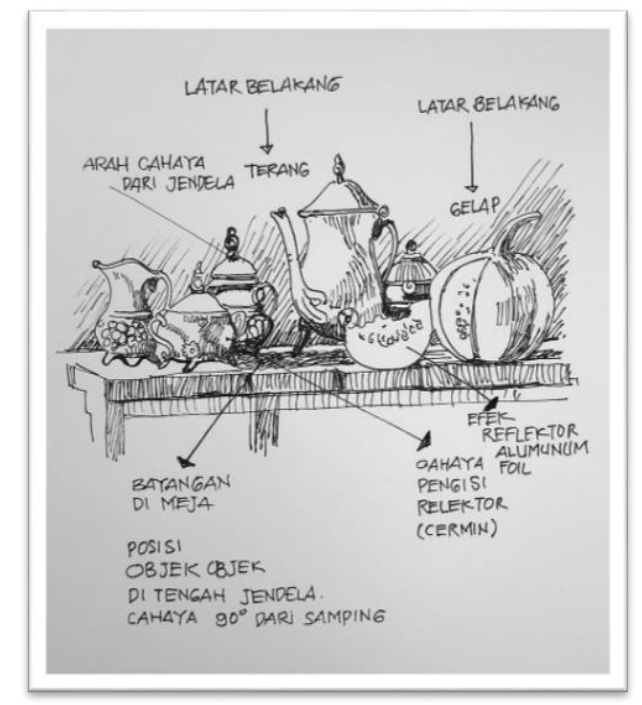

Gambar 3. Denah Denah posisi objek di tengah jendela. (Sumber: Dokumentasi Penulis)

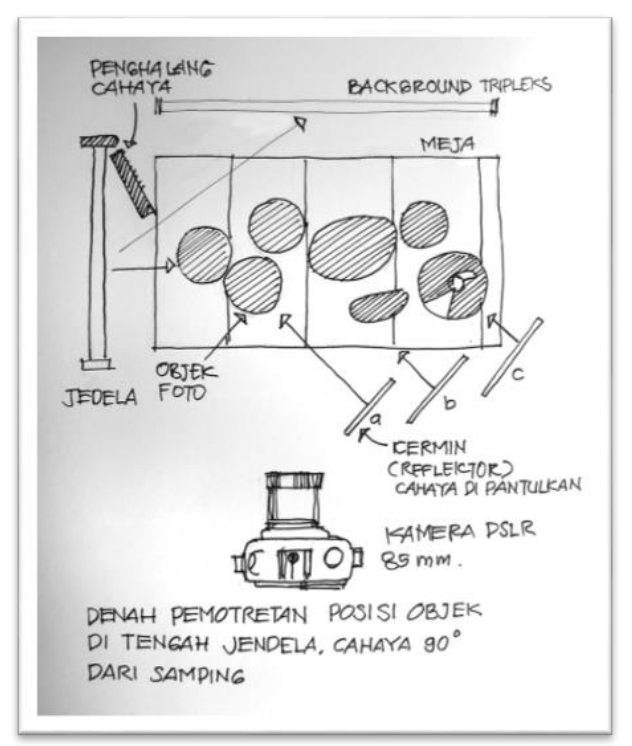

Gambar 4. Sketsa, posisi objek di tengah jendela. (Sumber: Dokumentasi Penulis) 


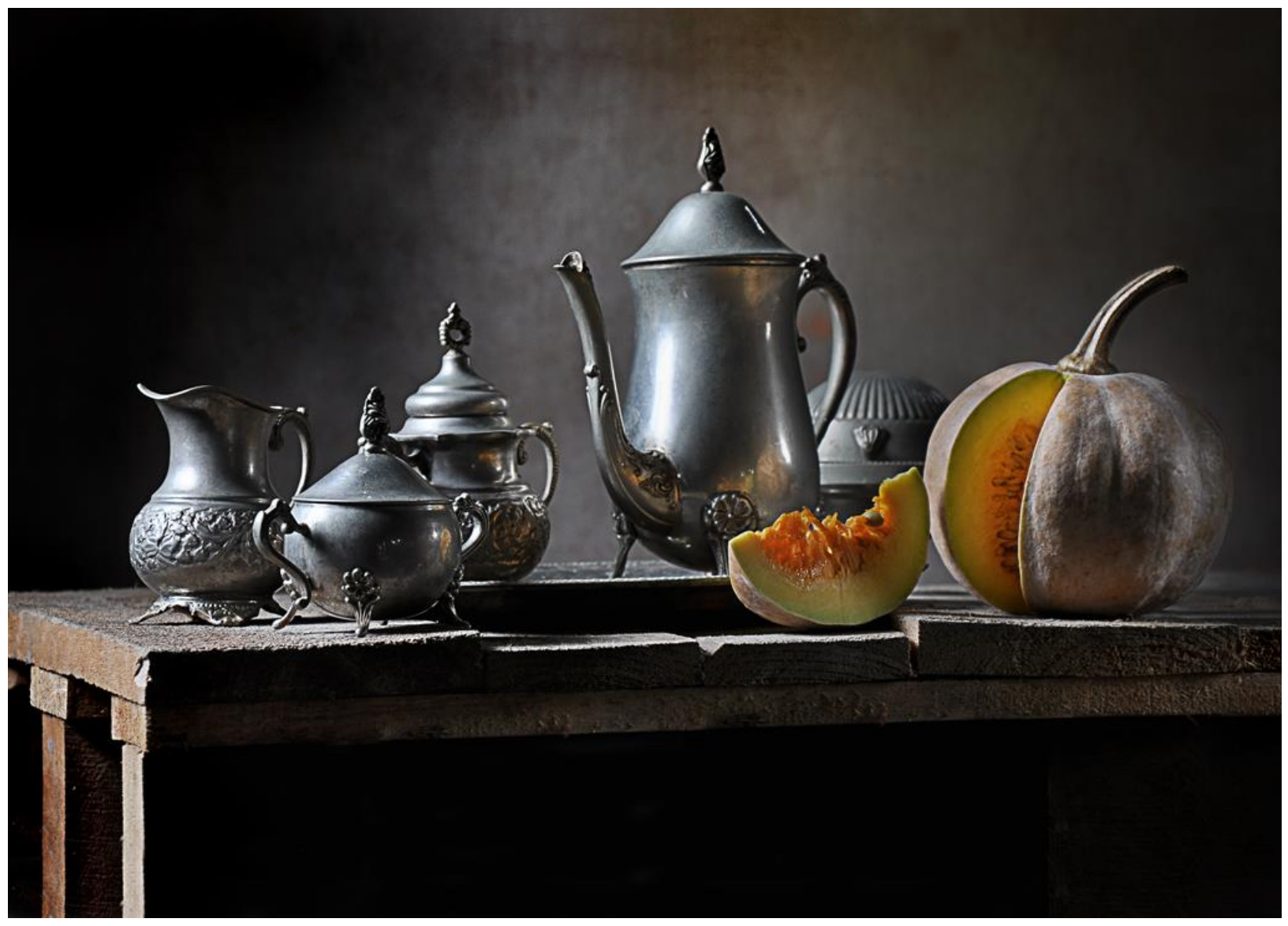

Gambar 5.Foto "Kenangan Lama”, objek di tengah jendela.

(Sumber: Dokumentasi Penulis)

Karya Bertina De Moij lainnya yang menggunakan cahaya dari jendela dilihat dari posisi objeknya terhadap jendela.

\subsection{Data Objek Kajian}

Objek kajian $\quad$ : Foto Alam Benda pada Poster Pameran tahun 2014

Judul Foto

: Kenangan Lama

Tema Pameran : Pameran Karya Mahasiswa Fotografi Dasar

Pelaksanaan Pameran : Galeri Visi 2010

Waktu

: 25 November - 3 Desember 2010

Karya

: Bertina De Moij

Teknik

: Window Lighting

Penataan

: Labu yang terpotong (pusat perhatian) diletakkan di titik strategis

mengikuti kaidah penataan objek dalam toeri komposisi golden ratio dari the rule of thurth. 


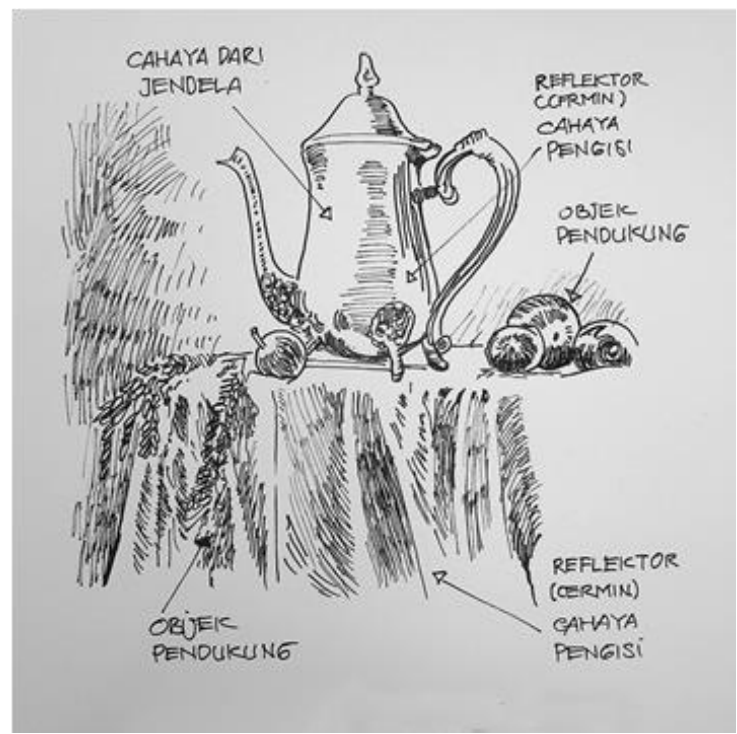

Gambar 6.Sketsa posisi objek di tengah jendela. (Sumber: Dokumentasi Penulis)

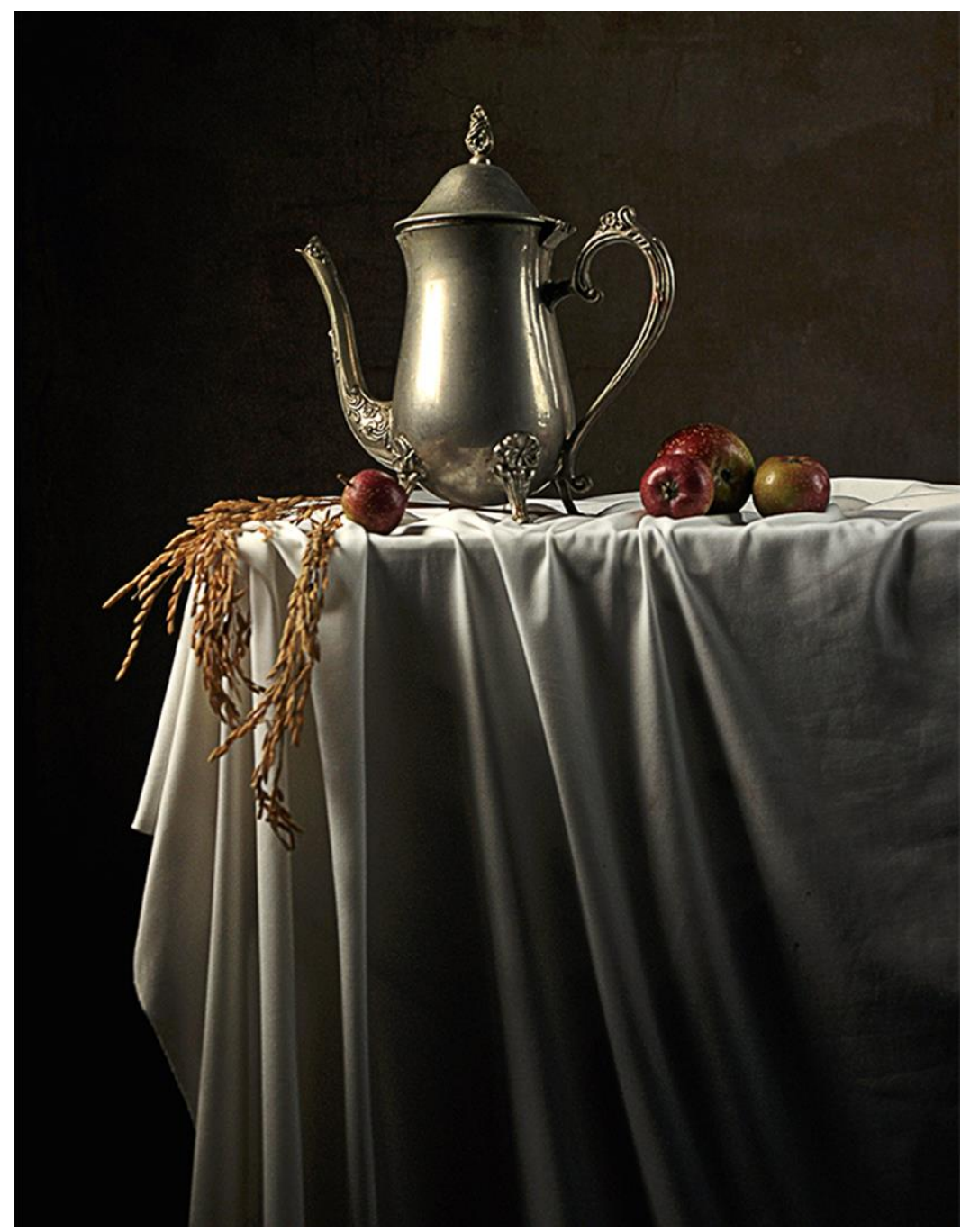

Gambar 7. Hasil pemotretan objek di tlengah jendela. (Sumber: Dokumentasi Penulis) 


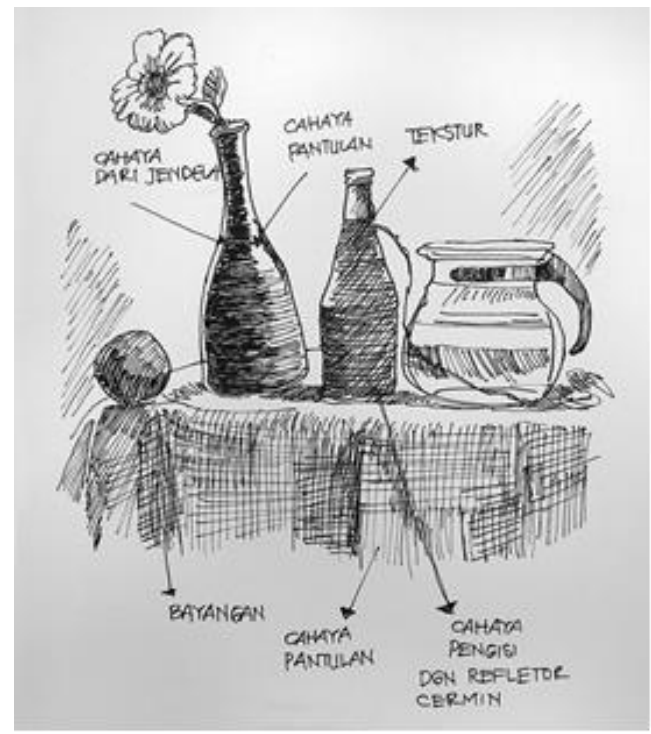

Gambar 8.Sketsa pemotretan objek di depan jendela.

(Sumber: Dokumentasi Penulis)

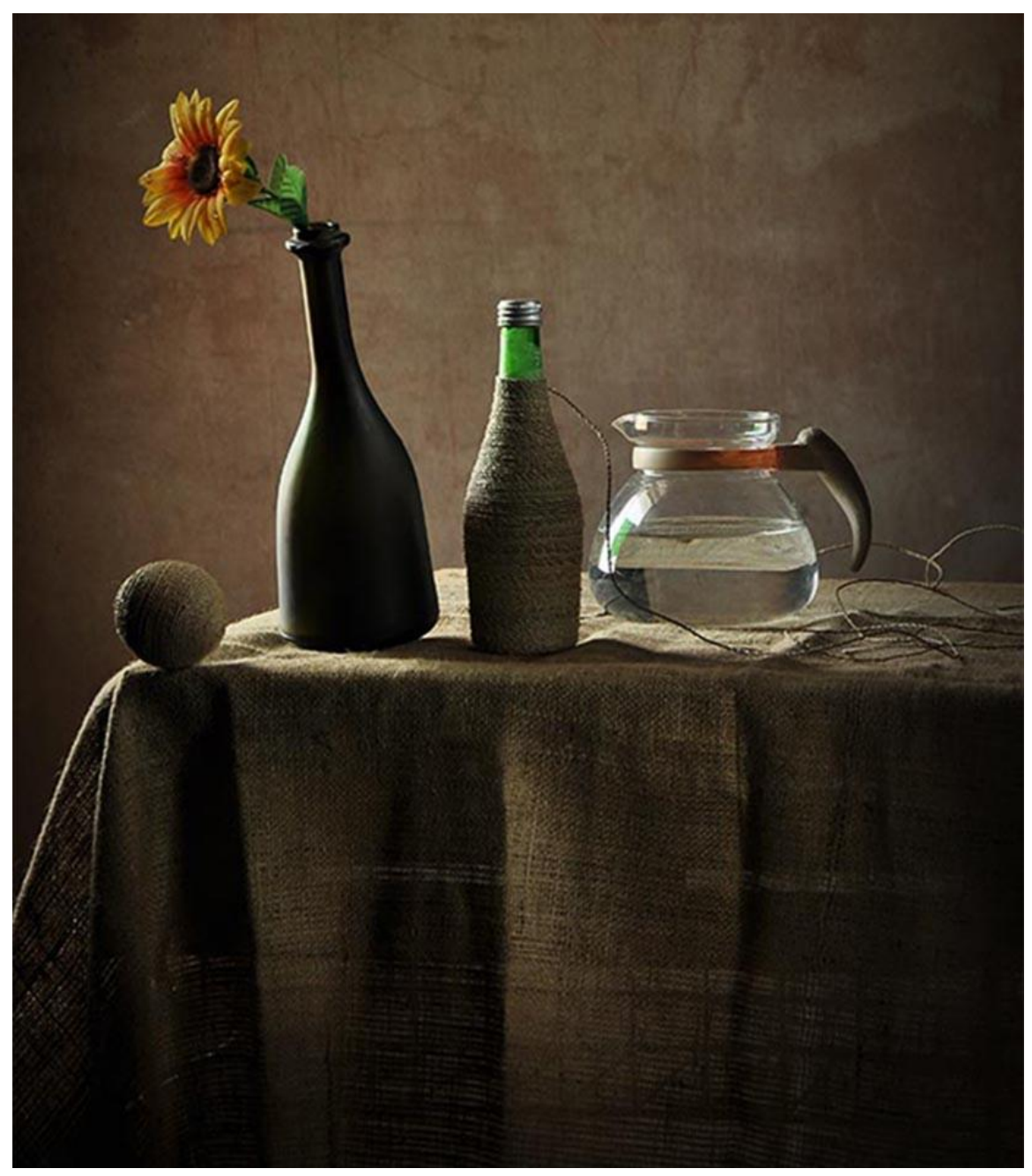

Gambar 9. Gambar 10. Hasil pemotretan objek di depan jendela. (Sumber: Dokumentasi Penulis) 


\subsection{Komposisi Pada Foto Alam Benda}

Foto bagus selain memuat ide/gagasan yang brilian, ia juga memenuhi unsur-unsur kebentukannya, seperti; keunikan objek, karaker permukaan yang menunjukkan spesifikasi dari benda. Bagaimana benda itu ditampilkan merupakan persoalan pelik yang kadang harus melibatkan cita-rasa dalam menciptakan susunannya. Objek alam benda tidak dipotret begitu saja, pemotret mengambil bagian dalam menetukan komposisi bagaimana baiknya objek-objek itu memenuhi frame kamera. Aspek yang perlu diperhatikan dalam penataan objek foto alam benda yaitu; Sudut pengambilan atau sudut pandang pemotretan, persolannya adalah seberapa luas area pandang yang akan ditampilan dapat ditentukan terlebih dahulu dengan kamera di atas tripod. Lensa bertitik api antara $85 \mathrm{~mm}$ - 135mm cukup tepat untuk objek alam benda, lensa ini akan menampilkan kesan senyatanya benda dengan proporsional tanpa distorsi.. Penggunaan lensa terlalu lebar dapat menyebabkan kesan tidak wajar un-proportional dari objek. Objek dengan jumlah di bawah sepuluh pengambilan dari dekat atau menampilkan objek dengan jelas lebih diperioritaskan. Tujuannya supaya setiap detail dan lekuk objek dapat diamati.

Menentukan komposisi memperhatikan azaz kesatuan (unity) yaitu ojek-objek yang dipilih sejenis dan relefan diletakkan di atas meja di dapur. Keseimbangan (balance) terlihat dari besarnya objek terhadap bidang gambar sebanding, artinya tidak terlalu sesak atau memenuhi bidang gambar dan juga tidak terlalu lengang atau dipotret lebih jauh (zoom out) sehingga objek tertalu kecil dan suasana disekitar objek lebih dominan. Irama (rhytm) komposisi mengikuti alur yang baik, objek utama (potongan labu terletak pada titik yang strategis mengikuti teori komposisi golden ratio dari the rule of thurth (Tjin, Enche. 2012).

Peranan cahaya dan komposisi dalam foto "kenangan lama" saling melengkapi artinya satu dan lainnya saling terkait untuk menciptakan keselarasan bentuknya yang harmoni. Cahaya dan komposisi saling bermperan menciptakan suasana ( $m o o d$ ) pada foto ini. Penataan cahaya dan komposisi pada foto "kenangan lama" sama pentingnya dan menampilkan citra visual foto tersebut. Komposisi menunjukkan cita-rasa artistik dari fotografernya yang dapat dilihat pada hasil foto, sedangkan cahaya dapat menunjukkan bahwa fungsi teknis dan artistiknya pada foto tersebut terpenuhi.

Eksposure adalah komponen yang akan menentukan kualitas gambar yang terekam di dalam kamera. Pada foto alam benda khususunya dengan teknik window lighting ISO ditentukan terlebih dahulu. Pilihan ISO rendah untuk kehalusan butiran gambar dan bukaan diafragma dapat diperioritaskan, selanjut menentukan fokus area (ruang tajam) foto tersebut. Shutter speed (rana) 
dapat menyesuaikan dengan pilihan under exposed 1/3 f stop karena kondisi objek dominan gelap.

Dengan adanya penelitian ini, diharapkan dapat menemukan sebuah formulasi dalam meneliti atau diagram yang tepat untuk pembuatan foto alam benda dengan teknik window ligjhting dengan kamera DSLR yang optimal. Penelitian ini juga dapat mempopulerkan kembali teknik window lighting untuk belajar memotret alam benda pada fotografi dasar. Penelitian ini juga bermanfaat untuk dijadikan panduan menciptakan foto alam benda untuk kebutuhan kartu ucapan, kalender atau karya seni untuk sebuah pameran.

\section{KESIMPULAN}

Dengan memahami teknik pencahayaan alam benda dengan cahaya dari jendela (window lighting), pemotret semakin mengetahui esensi dan konsep cahaya untuk foto alam benda yang sesungguhnya. Sehingga dapat dimanfaatkan untuk pembuatan foto alam benda yang baik. Terbukti bahwa cahaya memancar lurus dan dapat memunculkan citra (image) objek. Cahaya memiliki sudut pancar tertentu yang berpengaruh terhadap tingkat kekontrasan objek foto. Cahaya dapat berkurang kekuatannya cerahnya jika terhalang oleh benda atau tabir yang transparan. Foto alam benda (still life) digunakan sebagai media ekspresi dan dapat dilakukan siapa pun di dekat jendela rumahnya. dengan menggunakan Kamera DSLR, kamera mirrorless atau kamera pocket digital. Melalui foto alam benda pemotret dapat menyampaikan suatu artefak spesifik yang berasal dari masing-masing dearah dan dapat dijadikan media berekspresi melalui fotografi.

Pengaturan elemen-elemen visual dalam foto alam benda mempertimbangkan aspek unity, balance dan irama. Perpaduan teknik cahaya dan komposisi adalah bentuk kreativitas dan intelektual fotografer dalam proses penciptaan karyanya. Cahaya tidak rata tidak perlu dihindari justru sebagai tantangan untuk kreativitas pemotretnya. Cahaya dari jendela mampu menciptakan ilusi tiga dimensi dari objek dan menciptakan suasana (mood) pada foto. Melalui cahaya dari jendela siapa pun dapat membuat foto benda-benda yang disukainya. Dengan mempelajari teknik window lighting akan meningkatkan ketertarikan penggemar fotografi pada foto alam benda (still ife). Komposisi yang dinamis untuk foto alam benda lebih diutamakan untuk menghindari rasa kebosanan dalam melihatnya. Dalam foto "kenangan lama" Bertina De Moij memperhatikan semua aspek di atas. 


\section{DAFTAR PUSTAKA}

Langford, M. (1982). The Complete Encyclopedia of Photography: The Most Comprehensive Reference Work on Styles, Techniques Equipment, Processes and Practical Applications of The Photographer's Art. London: Dorlind Kindersley Limited.

Mulyadi, Erwin \& Tjin, E. (2014). Kamus Fotografi. Jakarta: PT. Elex Media Komputindo Kompas-Gramedia.

Perweiler, G. (1984). Secret of Studio Still Life Photography. New York: American Photographic Book.

Peterson, B. (2010). Pintar Exposure. Jakarta: Prigel Books.

Rosenblum, Naomi. (1984). A World History Of Photography. New York: Abbeville Press

Susanto, M. (2011). Diksi Rupa: Kumpulan Istilah dan Gerakan Seni Rupa. In Yogyakarta: DictiArt Lab \& Djagad Art House (p. 464 hlm).

Tjin, E. (2012). Fotografi Itu Mudah! 100 Tip dan Trik Dunia Fotografi. Jakarta: Bukune. Triadi, D. (2011). Secret Lighting. Jakarta: PT. Gramedia Pustaka Utama. 